\title{
Comparative Polyphenolic Content and Antioxidant Activities of Some Wild and Cultivated Blueberries from Romania
}

\author{
Andrea BUNEA, Dumitrița O. RUGINǍ, Adela M. PINTEA, Zorița \\ SCONT,A, Claudiu I. BUNEA, Carmen SOCACIU* \\ ${ }^{1}$ University of Agricultural Sciences and Veterinary Medicine, Cluj-Napoca, 3-5 Mănăştur Street, 400372, \\ Cluj-Napoca, România; carmen.socaciu@usamvcluj.ro ( ${ }^{*}$ corresponding author)
}

\begin{abstract}
Two wild and three cultivated blueberry varieties ('Elliot', 'Bluecrop' and 'Duke') from Romania were analyzed comparatively in order to determine the total polyphenols, total anthocyanins, total flavonoids content and measuring the antioxidant activity using three different single electron transfer-based assays, Trolox equivalent antioxidant capacity (ABTS), ferric reducing ability (FRAP), 2,2diphenylpicrylhydrazil radical scavenging capacity (DPPH) and one hydrogen atom transfer-assay, oxygen radical absorbance capacity (ORAC). Total polyphenols content ranged from 424.84 - $819.12 \mathrm{mg} \mathrm{GAE} / 100 \mathrm{~g} \mathrm{FW}$, total flavonoids ranged from 84.33-112.5 mg $\mathrm{QE} / 100 \mathrm{~g} \mathrm{FW}$ and total anthocyanins ranged from 100.58-300.02 C3GE/100g FW. The anthocyanins were separated and quantified using RP-HPLC-DAD. In Vaccinium myrtillus, petunidin-3-glucoside and delphinidin-3-glucoside have the highest contribution to the anthocyanin content while in Vaccinium corymbosum, peonidin-3-galactoside represent the major anthocyanin. Except for ORAC assay $(r=0.765)$, all antioxidant activity values obtained were highly correlated with total polyphenol content $(0.923 \leq \mathrm{r} \leq 0.986)$. Wild blueberries had higher total polyphenols content and also antioxidant activity compared with cultivated ones.
\end{abstract}

Keywords: Vaccinium myrtillus, Vaccinium corymbosum, total polyphenols, anthocyanins, antioxidant methods

Abbreviations: TPC, total polyphenols content; TA, total anthocyanins; TF, total flavonoids; FRAP, ferric reducing antioxidant potential; ABTS, trolox equivalent antioxidant capacity; ORAC, oxygen radical absorbing capacity; DPPH, 2,2-diphenyl-1picrylhydrazyl method, TE, Trolox equivalents, Trolox, 6-hydroxy-2,5,7,8-tetrametylchroman-2-carboxylic acid

\section{Introduction}

The interest for natural antioxidants, especially from fruits and vegetables, has increased in recent years. Epidemiological studies indicated that a higher level of natural antioxidants (ascorbic acids, vitamin E, carotenoids and phenolics) in human everyday diet can protect against cardiovascular diseases, cataract, cancer and aging-related disorders (Steffen et al., 2003).

Berries contain high concentration in bioactive compounds such as polyphenols, including anthocyanins, phenolic acids, tannins, carotenoids, vitamin A, C, E, folic acid and minerals such as calcium, selenium and zinc (Kresty et al., 2001; Pineli et al., 2011). Among them, blueberries became well known and often consumed due to their uses for treating biliary disorders, coughs, tuberculosis, diabetes (Martineau et al., 2006; Valentová et al., 2007) and visual disorders (Canter and Ernst, 2004). Blueberries contain high level of anthocyanin and phenolic compounds with high in vitro antioxidant capacities compared with other fruits (Wang and Jiao, 2000). The blueberries phenolic content are affected by genetic differences, the cultivar type, growing location and the degree of maturity at harvest (Zadernowski et al., 2005). The total amount and the proportion between different classes of phenolic compounds in berries cultivar may vary (Beekwilder et al., 2005).

The methods used to determine the total antioxidant capacity can be divided in two major groups: methods based on single electron transfer (SET) and hydrogen atom transfer reaction (HAT). The SET methods include ABTS/TEAC assay (Trolox equivalent antioxidant capacity), FRAP (ferric reducing ability), CUPRAC assay (copper reduction) and DPPH assay (2,2-diphenylpicrylhydrazil radical scavenging capacity). Hydrogen atom transfer reaction (HAT) assay include ORAC (oxygen radical absorbance capacity) and TRAP (total radicaltrapping antioxidant parameter) assay. These assays are frequently used to measure the total antioxidant capacity of food extracts. Because their characteristics and because of the differences in the mechanisms of the reaction, a single assay will not reflect all the antioxidants present in the system (Li et al., 2009). Hence, only by combining different assays, information about the response of the compounds present in samples in different experimental conditions can be achieved (Sariburun et al., 2010). 
The literature data about blueberries antioxidant activity and total polyphenol content are diverse, more on cultivated than wild varieties (Castrejón et al., 2008; DragovićUzelac et al., 2010; Garzón et al., 2010; Giovanelli and Buratti, 2009; Howard et al., 2003; Koca and Karadeniz, 2009; Prior et al., 1998; You et al., 2011).

The objectives of this study were (1) to investigate total polyphenols, total flavonoids, total anthocyanins content of blueberry extracts, (2) to separate and characterize the anthocyanin content using RP-HPLC-DAD, (3) to measure the antioxidant activity using three different SET-based assays (ABTS, FRAP, DPPH) and one HATbased method (ORAC), (4) to correlate the antioxidant methods applied with total polyphenol, total flavonoid and total anthocyanin content.

\section{Materials and methods}

\section{Chemicals}

The standard compounds, including cyanidin-3-Ogalactoside (purity 90\%), cyanidin-3-O-glucoside (purity 95\%), cyanidin (purity 95\%), gallic acid (GAE) (purity 97.5\%), quercetin (purity 98\%) and 2,2'-azobis (2-amidinopropane) dihydrochloride (AAPH) 97\% purity ,6-hydroxy-2,5,7,8-tetramethylchroman-2-carboxylic acid (Trolox) 98\% purity, fluorescein 97\% purity, 2,9-dimetyl-1,10-phenanthroline (Neocuproine) 99\% purity, 2,2-azinobis(3-ethylbenzothiazoline-6-sulfonic acid), diammonium salt (ABTS) 98\% purity, 2,2-diphenyl-1picrylhydrazyl (DPPH) 95\% purity, 2,4,6-tripyrydyl-Striazine (TPTZ) 98\% purity, potassium persulfate were obtained from Sigma-Aldrich (Darmstadt, Germany). Folin-Ciocalteu's phenol reagent, $\mathrm{HCl}, \mathrm{Na}_{2} \mathrm{CO}_{3} \mathrm{AlCl}_{3}$, $\mathrm{NaNO}_{2}, \mathrm{H}_{2} \mathrm{O}_{2}, \mathrm{CuCl}_{2}$ were purchased from Merck (Darmstadt, Germany).

\section{Samples extraction}

Three varieties of cultivated highbush blueberries ( $\mathrm{Vac}$ cinium corymbosum) 'Elliot', 'Bluecrop' and 'Duke' were purchased directly from the producers, a farm situated in North-West of Romania. The two types of wild blueberries (Vaccinium myrtillus, Wild 1 and Wild 2) were harvested from two different mountainous geographical zones: $45^{\circ} 24^{\prime} 44^{\prime \prime} \mathrm{N}$ and $46^{\circ} 44^{\prime} 37^{\prime \prime} \mathrm{E}$ of Romania. All berries were picked at the commercially ripe stage. Samples were stored in a freezer at $-20^{\circ} \mathrm{C}$ until analyzed.

For sample extraction, $5 \mathrm{~g}$ of blueberries, in three replicated each, was extracted by grinding the sample $1 \mathrm{~min}$ at 20,000 rpm in a blender (Ultra-Turrax Miccra D-9 KT Digitronic, Germany) with $10 \mathrm{ml}$ of acidified methanol (85:15 v/v, MeOH:HCl) (El-Sayed and Hucl, 2003). The homogenate was centrifuged at $3500 \mathrm{rpm}$ for $10 \mathrm{~min}$. The extract was separated and the residual tissue was reextracted until the extraction solvents became colorless (the total solvent volume was between $100-250 \mathrm{ml}$ ). After adding $10 \mathrm{ml}$ of the same solvent mixture, the extraction was carried out under stirring. The filtrates were combined in a total extract, which was dried by vacuum rotary evaporator at $40^{\circ} \mathrm{C}$. Prior to each analysis, the dry residues were redisolved in $10 \mathrm{ml}$ of methanol, the samples were centrifuged at $5000 \mathrm{rpm}$ and filtered through $0.45 \mu \mathrm{m}$ nylon filter (Millipore).

\section{Total phenolics}

The amount of total polyphenol in the blueberry extracts was determined using modified Folin-Ciocalteu colorimetric method (Singleton et al., 1999). Stock solution of sample extracts $(25 \mu \mathrm{l}$ each) were dissolved in methanol and further dilution were performed to obtain readings within the standard curve made with gallic acid $(\mathrm{R}=0.997)$. The extracts were oxidized by the Folin-Ciocalteu reagent $(120 \mu \mathrm{l})$ and the neutralization was made with $\mathrm{Na}_{2} \mathrm{CO}_{3}(340 \mu \mathrm{l})$, after 5 minutes. The absorbance was measured at $750 \mathrm{~nm}$ after 90 minute in the dark, at room temperature. The results were expressed as milligram of gallic acid per 100 grams.

\section{Total flavonoids}

The total flavonoids content was determined using a colorimetric method (Kim et al., 2003). The alcoholic extract was diluted to a final volume of $5 \mathrm{ml}$ with distilled water. After adding $300 \mu \mathrm{l} 5 \% \mathrm{NaNO}_{2}$ the mixture was allowed to stay $5 \mathrm{~min}$. Then $300 \mu \mathrm{l} \mathrm{AlCl} \mathrm{Al}_{3} 10 \%$ was added and, after 6 minutes, $2 \mathrm{ml} \mathrm{NaOH} 1 \mathrm{~N}$. The solution was mixed well and the absorbance was measured against prepared water blank at $510 \mathrm{~nm}$. Total flavonoid content was expressed as $\mathrm{mg}$ quercetin equivalents/100 $\mathrm{g}$ fresh weight basis.

\section{Quantification of the anthocyanin content}

The monomeric anthocyanin content of the blueberry extract was measured using the $\mathrm{pH}$-differential method (Giusti and Wrolstad, 2001). The blueberry extracts dissolved in methanol were diluted with $0.025 \mathrm{~mol} / \mathrm{l}$ potassium chloride (adjusted with $\mathrm{HCl}$ to $\mathrm{pH} 1.0$ ) and $0.4 \mathrm{~mol} / \mathrm{l}$ sodium acetate $(\mathrm{pH} 4.5)$. Each sample and the standard (cyanidin-3-glucoside) were diluted with the buffer solution $\mathrm{pH} 1$ and the absorbance was measured at $520 \mathrm{~nm}$ and $700 \mathrm{~nm}$ using a UV spectrophotometer (Jasco V-630, International Co. Ltd, Japan). A second aliquot of each sample was diluted to the same value with the buffer solution $\mathrm{pH} 4.5$ and measured at 520 and $700 \mathrm{~nm}$. The absorbance values were calculated as follows:

$\mathrm{A}=\left(\mathrm{A}_{\lambda 520}-\mathrm{A}_{\lambda 700}\right)_{\mathrm{pH} 1.0}-\left(\mathrm{A}_{\lambda 520}-\mathrm{A}_{\lambda 700}\right)_{\mathrm{pH} 4.5}$

The total anthocyanin content was calculated according to the formula:

$$
\mathrm{TA}=\frac{\mathrm{A} \times \mathrm{MW} \times \mathrm{DF} \times 1000}{\varepsilon \times 1}
$$

The results were expressed as mg cyanidin-3-glucoside chloride per $100 \mathrm{~g}$ fruit using the molar absorbtivity $(\varepsilon)$ 
72

in methanol/ $\mathrm{HCl}$ of $34300\left(\mathrm{M}^{-1} \mathrm{~cm}^{-1}\right)$, molecular weight (MW) of 484.8 and dilution factor (DF).

\section{Anthocyanin determination by RP-HPLC-DAD}

Analyses were performed on a Shimadzu HPLC system equipped with a binary pump delivery system LC-20 AT (Prominence), a degasser DGU-20 A3 (Prominence), diode-array SPDM20 A UV-VIS detector (DAD) and a Luna Phenomenex C-18 column ( $5 \mu \mathrm{m}, 25 \mathrm{~cm}$ x $4.6 \mathrm{~mm})$. The mobile phase consisted in: solvent A - formic acid (4.5\%) in bidistilled water and solvent B - acetonitrile. The gradient elution system was: $10 \% \mathrm{~B}, 0-9 \mathrm{~min} ; 12 \% \mathrm{~B}, 9-17$ min; 25\% B 17-30 min; 90\% B, 30-50 min; 10\% B, 50-55 $\mathrm{min}$. The flow rate was $0.8 \mathrm{ml} / \mathrm{min}$ and the analyses were performed at $35^{\circ} \mathrm{C}$. The chromatograms were monitored at $520 \mathrm{~nm}$. The anthocyanins identification and peak assignments are based on their retention times, UV-VIS spectra comparing with standards and published data. The anthocyanin quantification was performed using cyanidin 3-O-galactoside.

\section{Oxygen radical absorbance activity $(O R A C)$}

The oxygen radical absorbance capacity (ORAC) measure the peroxyl radical scavenging activity using as standard 6-hydroxy-2,5,7,8-tetrametylchroman-2-carboxylic acid (Trolox) (Huang et al., 2002). A fluorescein stock solution $\left(4 \times 10^{-3} \mu \mathrm{M}\right)$ was made in phosphate buffer $(75$ $\mathrm{mM}, \mathrm{pH} 7.4)$ and kept in the dark at $4^{\circ} \mathrm{C}$. Before utilization, the fluorescein stock solution was diluted with the phosphate buffer. The fluorescein solution was added to each Trolox standard and blueberry sample $(25 \mu \mathrm{l})$ made in phosphate buffer and incubated for $30 \mathrm{~min}$, at $37^{\circ} \mathrm{C}$. The reaction was initiated by adding $25 \mu \mathrm{l} 2,2$-azobis-2amidinopropane $(\mathrm{AAPH})$ and the fluorescence was measured kinetically at excitation wavelength $485 \mathrm{~nm}$ and emission wavelength $535 \mathrm{~nm}$, every minute using a fluorescence microplate reader BioTek (Synergy HT, BioTek Instruments, Winooski, VT). The ORAC values for each blueberry extract were calculated using the net area under the decay curves and were expressed as micromoles Trolox equivalents per gram sample ( $\mu \mathrm{mol} \mathrm{TE} / \mathrm{g})$.

\section{ABTS radical cation decolorization assay (ABTS)}

The ABTS assay is based on the capacity of a sample to scavenge the ABTS radical cation $\left(\mathrm{ABTS}^{+}\right.$) compared to a standard antioxidant (Trolox), adapted to 96 wells microplate, described by Arnao et al. (2001). The ABTS ${ }^{+}$ solution was produced by reacting $7 \mathrm{mM}$ ABTS stock solution with $2.45 \mathrm{mM}$ potassium persulfate (final concentration) for $12-16 \mathrm{~h}$, in the dark, at room temperature. Prior to use, the ABTS ${ }^{+}$working solution was prepared by diluting the stock solution with $\mathrm{EtOH}$ to an absorbance of $0.70 \pm 0.02$ at $734 \mathrm{~nm}$. The samples and Trolox standards $(20 \mu \mathrm{l})$ were combined with the ABTS ${ }^{+}$working solution (170 l, absorbance $0.70 \pm 0.02$ ) in 96-well microplate. After 6 min of incubation at $30^{\circ} \mathrm{C}$, the absorbance at 734 $\mathrm{nm}$ was read with a microplate reader. If the absorbance of ABTS value was higher than the standard, the samples were diluted and re-evaluated. The results were expressed as micromoles Trolox equivalents per gram sample (TE $\mu \mathrm{mol} / \mathrm{g})$.

\section{Reducing power (FRAP)}

The reducing capacity of methanolic blueberry extracts was measured as ferric reducing antioxidant power (FRAP). Antioxidants are evaluated as reducers of $\mathrm{Fe}^{3+}$ to $\mathrm{Fe}^{2+}$, which is chelated by TPTZ to form $\mathrm{Fe}^{2+}$ - TPTZ complex, with a maximum absorbance at $593 \mathrm{~nm}$ (Benzie and Strain, 1996). The absorbance of the colored product was monitored by Biotek Synergy HT spectrophotometer. All solutions were used in the day of preparation. Briefly, $2.5 \mathrm{ml} \mathrm{TPTZ}(10 \mathrm{mM}$ in $40 \mathrm{nM} \mathrm{HCl}), 25 \mathrm{ml}$ acetate buffer $(300 \mathrm{mM}, \mathrm{pH}=3.6)$ and $2.5 \mathrm{ml} \mathrm{FeCl}_{3}(20 \mathrm{mM})$ were mixed and after adding $180 \mu \mathrm{l}$ FRAP reagent the mixture was incubated for $3 \mathrm{~min}$. Then, $20 \mu \mathrm{l}$ of each sample added to each well and the absorbance was read immediately at $593 \mathrm{~nm}$ with a microplate reader. Samples dilution were perfomed when the values were over the linear range of the curve of 0 to $1 \mu \mathrm{M} \mathrm{Fe}^{2+} / \mathrm{ml}$, using $\mathrm{FeSO}_{4} \times 7 \mathrm{H}_{2} \mathrm{O}$.

\section{$D P P H \cdot$ scavenging activity assay}

The DPPH scavenging activity assay was done according to a method reported by Brand-Williams et al. (1995). A DPPH. solution $(80 \mu \mathrm{M})$ was freshly prepared in $95 \%$ methanol. A volume of $250 \mu \mathrm{l}$ of this solution was allowed to react with $35 \mu \mathrm{l}$ sample and the absorbance was measured at $515 \mathrm{~nm}$, for 30 minutes. The chemical kinetics of blueberries extract was recorded. The antioxidant activity was calculated as follows:

$\% \mathrm{DPPH} \cdot$ scavenging activity $=\left(1-\left[\mathrm{A}_{\text {sample }} / \mathrm{A}_{\text {control }=0}\right]\right) 100$

\section{Statistical analysis}

The data's are expressed as mean \pm standard deviation (SD) from three parallel measurements. In order to determine the significant differences between values, analysis of variance (ANOVA) and Duncan's multiple range tests were performed. Significance of difference was defined at the $5 \%$ level $(p<0.05)$. All statistical analysis was carried out using Graph Pad Version 4.0 (Graph Pad Software Inc; San Diego, CA, USA). Pearson's correlation coefficient was calculated using Microsoft Excel 2003.

\section{Results and discussion}

\section{Total polyphenols content}

The comparative data about total polyphenols, flavonoids and anthocyanins content in wild and cultivated blueberries are presented in Tab. 1 .

The total polyphenols content (TPC) was determined using the Folin-Ciocalteu method. Gallic acid was used as calibration standard and the results (expressed as gallic acid equivalents) were expressed as means \pm standard deviation of triplicate analysis. The TPC values in the blueberry extracts analyzed was in the range of $424.84-819.12 \mathrm{mg}$ 
Tab. 1. Total polyphenols, total flavonoids and total anthocyanins content in wild and cultivated blueberries

\begin{tabular}{|c|c|c|c|}
\hline & $\begin{array}{c}\text { Total } \\
\text { polyphenols } \\
\text { GAE mg/100 g }\end{array}$ & $\begin{array}{c}\text { Total } \\
\text { flavonoids } \\
\mathrm{mg} \mathrm{QE} / 100 \mathrm{~g}\end{array}$ & $\begin{array}{c}\text { Total } \\
\text { anthocyanins } \\
\text { C3GE mg/100 g }\end{array}$ \\
\hline \multicolumn{4}{|c|}{ Vaccinium corymbosum } \\
\hline 'Elliot' & $526.3 \pm 26^{d}$ & $92.82 \pm 8.4^{\mathrm{a}}$ & $163.40 \pm 16.4^{c}$ \\
\hline 'Bluecrop' & $652.27 \pm 30^{c}$ & $103.18 \pm 10.2^{\mathrm{a}}$ & $160.76 \pm 13.9^{c}$ \\
\hline 'Duke' & $424.84 \pm 20^{\mathrm{c}}$ & $84.33 \pm 8^{b}$ & $100.58 \pm 13.5^{\mathrm{d}}$ \\
\hline \multicolumn{4}{|c|}{ Vaccinium myrtillus } \\
\hline Wild 1 & $819.12 \pm 36^{a}$ & $110.36 \pm 12.3^{a}$ & $300.02 \pm 27.9^{a}$ \\
\hline Wild 2 & $672.59 \pm 30^{\mathrm{b}}$ & $112.50 \pm 15^{a}$ & $252.23 \pm 18^{\mathrm{b}}$ \\
\hline \multicolumn{4}{|c|}{$\begin{array}{l}\mathrm{GAE} \mathrm{mg} / 100 \mathrm{~g} \text {, QE } \mathrm{mg} / 100 \mathrm{~g} \text {, and C3GE } \mathrm{mg} / 100 \mathrm{~g} \text { represent } \mathrm{mg} \text { of gallic } \\
\text { acid equivalents, } \mathrm{mg} \text { of quercetin equivalents and } \mathrm{mg} \text { of cyanidin-3-glucoside } \\
\text { equivalents per } 100 \mathrm{~g} \text { of fresh blueberry, respectively. For each measurements, } \\
\text { the data marked by different letters indicate significant difference }(\mathrm{p}<0.05)\end{array}$} \\
\hline
\end{tabular}

$\mathrm{GAE} / 100 \mathrm{~g}$ fresh weight. Among all the varieties analyzed, the Wild 1 blueberry revealed the highest TPC at 819.12 gallic acid equivalents $/ 100 \mathrm{~g} \mathrm{FW}$ followed by Wild 2 blueberries (672.59 mg GAE/100g). Between the cultivated blueberries, 'Bluecrop' has the highest TPC at $652.27 \mathrm{mg}$ $\mathrm{GAE} / 100 \mathrm{~g}$ while the lowest value was found for 'Duke' variety (424.84 mg GAE/100g). Significant differences were found in total phenolic content when compared all the varieties analyzed $(\mathrm{p}<0.05)$.

The TPC data's obtained are comparable to previous findings which reported values between 251-310 mg GAE/100 $\mathrm{g}$ for some cultivated blueberries and between 577 and $614 \mathrm{mg} \mathrm{GAE} / 100 \mathrm{~g}$ for wild Italian blueberries (Giovanelli and Buratti, 2009). Lee et al. (2004) obtained between 367-1286 mg GAE/100 g total polyphenols for V. membranaceum and for V. ovalifolium species 677$1054 \mathrm{mg}$ GAE/100 g. Prior et al. (1998) reported values between 181 and $390 \mathrm{mg} / 100 \mathrm{~g}$ for V. corymbosum L species. Dragovič-Uzelac et al. (2010) reported for 'Bluecrop' variety higher amount compared with 'Duke', while Prior et al. (1998) obtained higher TPC values for 'Duke' vari- ety. It is known that phenolics show quantitative variation at different genetic levels within species.

\section{Total flavonoids content}

The total flavonoids content of the extracts was determined using aluminium chloride colorimetric method and the results are shown in Tab. 1. The total flavonoids content ranged from $84.33 \mathrm{mg} Q E / 100 \mathrm{~g}$ in 'Duke' variety to $112.5 \mathrm{mg} \mathrm{QE} / 100 \mathrm{~g}$ in Wild 2 blueberries. For the other blueberry varieties the TFC were as follows: Wild 1 (110.36 mg QE/100 g), 'Bluecrop' (103.18 mg QE/100 g), 'Elliot' (92.82 mg QE/100 g) and 'Duke' ( $84.33 \mathrm{mg}$ $\mathrm{QE} / 100 \mathrm{~g}$ ). There were no significant differences in total flavonoid content among 'Elliot', 'Bluecrop', Wild 1 and Wild $2(\mathrm{p}<0.05)$. 'Duke' variety has the lowest total flavonoid content, significantly different than other varieties analyzed. There are no data regarding the total content of flavonoids in blueberries. In blackberry varieties, the TFC content range between 29.07-82.21 mg QE/100 g (Sariburun et al., 2010).

\section{Total anthocyanins content}

The total anthocyanins content (TAC) of the blueberries extract were also determined (Tab. 1). The highest anthocyanins content was found in wild blueberries Wild $1(300.02 \mathrm{mg} / 100 \mathrm{~g})$, followed by wild blueberries Wild $2(252.23 \mathrm{mg} / 100 \mathrm{~g})$, 'Elliot' $(163.4 \mathrm{mg} / 100 \mathrm{~g})$, 'Bluecrop' $(160.76 \mathrm{mg} / 100 \mathrm{~g})$ and the lowest TAC was found in 'Duke' variety $(69.58 \mathrm{mg} / 100 \mathrm{~g})$. There were significant differences $(p<0.05)$ in anthocyanins content between Wild 1, Wild 2 and 'Duke'. However, significant differences in the total anthocyanin content were not observed between 'Elliot' and 'Bluecrop' $(\mathrm{p}<0.05)$. The levels of TAC in TPC are between $23 \%$ and $37 \%$ and they are in agreement with the data's reported by other authors (Giovanelli and Buratti, 2009). The present TAC values obtained are in agreement with other studies (Dragovič-Uzelac et al., 2010; Prior et al., 1998).

Tab. 2. Concentration of individual anthocyanins in blueberries (expressed in $\mathrm{mg} / 100 \mathrm{~g}$ fruit)

\begin{tabular}{|c|c|c|c|c|c|c|c|}
\hline \multirow{2}{*}{ Compound } & \multirow{2}{*}{$\begin{array}{c}\text { Retention } \\
\text { time }\end{array}$} & \multirow{2}{*}{$\begin{array}{l}\text { Maximum } \\
\text { absorbance }\end{array}$} & \multicolumn{2}{|c|}{ Vaccinium myrtillus } & \multicolumn{3}{|c|}{ Vaccinium corymbosum } \\
\hline & & & Wild 1 & Wild 2 & 'Bluecrop' & 'Elliot' & 'Duke' \\
\hline Delphinidin-3-galactoside & 9.2 & $217 ; 277 ; 523$ & $113.67 \pm 11$ & $73.43 \pm 8.1$ & $53.29 \pm 7.2$ & ND & ND \\
\hline Delphinidin-3-glucoside & 10.6 & $217 ; 277 ; 523$ & $119.86 \pm 14$ & $87.14 \pm 8.2$ & $24.53 \pm 2$ & $53.62 \pm 7$ & $23.69 \pm 2.4$ \\
\hline Cyanidin-3-galactoside & 12.4 & $217 ; 279 ; 518$ & $91.85 \pm 10$ & $37.95 \pm 4.3$ & $9.96 \pm 1.8$ & ND & ND \\
\hline Delphinidin-3-arabinoside & 13.01 & $217 ; 277 ; 529$ & $66.64 \pm 9.2$ & $76.35 \pm 8.8$ & $31.78 \pm 2.6$ & $41.07 \pm 5.1$ & $13.64 \pm 1.1$ \\
\hline Cyanidin-3-glucoside & 14.4 & $217 ; 279 ; 518$ & $96.48 \pm 11$ & $43.34 \pm 6.1$ & $2.08 \pm 0.4$ & $3.09 \pm 0.6$ & $0.11 \pm$ \\
\hline Petunidin-3-galactoside & 15.09 & $217 ; 277 ; 524$ & $38.36 \pm 5.2$ & $17.53 \pm 0.9$ & $28.54 \pm 2.5$ & ND & ND \\
\hline Petunidin-3-glucoside & 16.9 & $217 ; 278 ; 521$ & $146.27 \pm 18$ & $85.19 \pm 7.8$ & $25.14 \pm 2.5$ & $21.35 \pm 1.9$ & $8.18 \pm 0.9$ \\
\hline Peonidin-3-galactoside & 19.4 & $217 ; 278 ; 520$ & $8.71 \pm 1.3$ & ND & ND & $125.79 \pm 12$ & 37.114 .3 \\
\hline Petunidin-3-arabinoside & 20.3 & $217 ; 277 ; 525$ & $12.80 \pm 1.9$ & $9.66 \pm 1.2$ & $12.70 \pm 1.9$ & ND & ND \\
\hline Peonidin-3-glucoside & 22.4 & $217 ; 278 ; 521$ & $108.81 \pm 12$ & $28.91 \pm 2.2$ & $54.37 \pm 7.5$ & $12 \pm 0.9$ & $12.14 \pm 1.1$ \\
\hline Malvidin-3-galactoside & 25.3 & $217 ; 278 ; 527$ & $119.53 \pm 12$ & $39.00 \pm 4.3$ & $37.97 \pm 2.6$ & $67.45 \pm 9$ & $27.55 \pm 2.4$ \\
\hline Malvidin-3-glucoside & 27.4 & $217 ; 277 ; 528$ & $17.51 \pm 3.2$ & $6.04 \pm 1.1$ & $34.75 \pm 2.5$ & ND & ND \\
\hline Malvidin-3-arabinoside & 29.5 & $217 ; 277 ; 528$ & $\operatorname{tr}$ & $\operatorname{tr}$ & ND & ND & ND \\
\hline
\end{tabular}




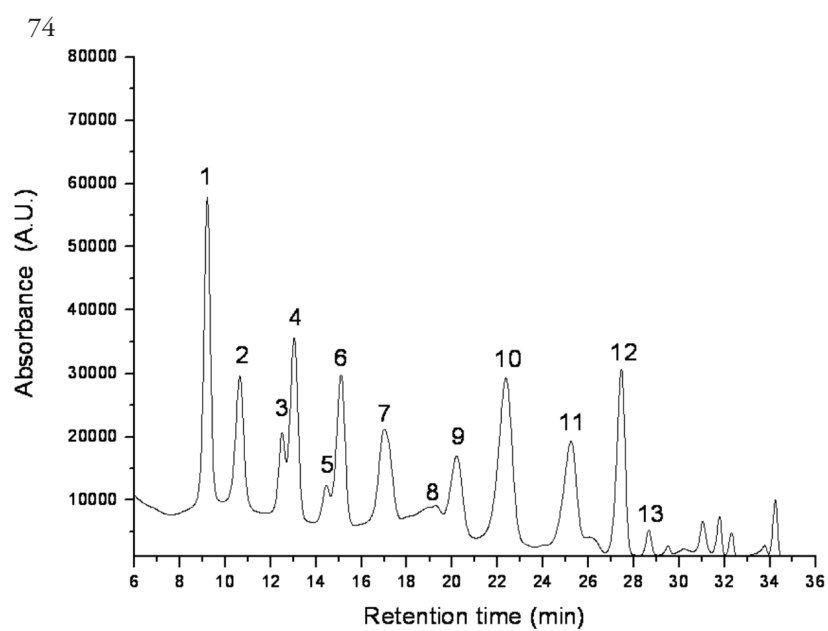

Fig. 1. Anthocyanin HPLC profiles for 'Bluecrop' variety. Peak identification: 1- Delphinidin-3-galactoside; 2- Delphinidin3-glucoside; 3-Cyanidin-3-galactoside; 4- Delphinidin-3-arabinoside; 5- Cyanidin-3-glucoside; 6-Petunidin-3-galactoside; 7-Petunidin-3-glucoside; 8-Peonidin-3-galactoside; 9-Petunidin-3-arabinoside; 10-Peonidin-3-glucoside; 11 -Malvidin-3-galactoside; 12-Malvidin-3-glucoside; 13-Malvidin-3-arabinoside

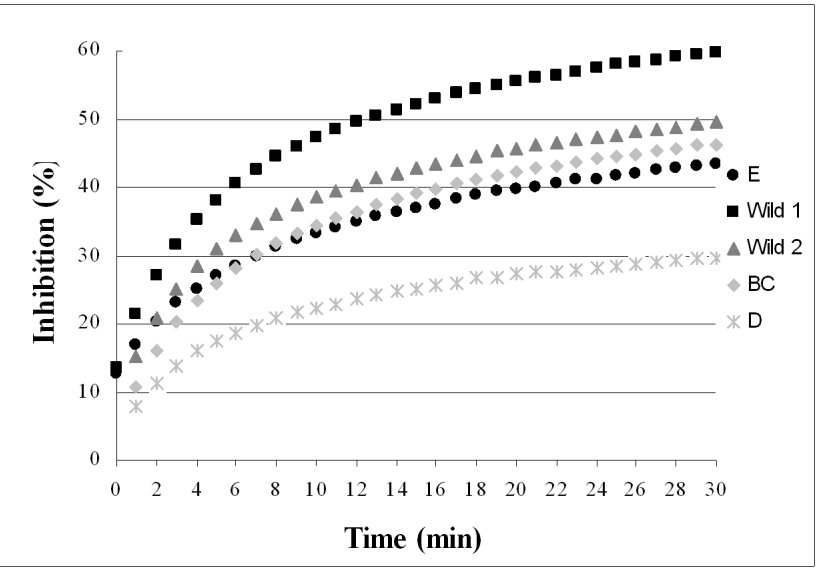

Fig. 2. Kinetics of antioxidant activity of blueberry extracts using DPPH method. The inhibition percentage represents the antioxidant activity

\section{Identification and quantification of anthocyanins}

Using HPLC-DAD, 13 anthocyanins were identified based on their retention time, UV-VIS spectra compared with standards and published data. HPLC chromatogram for anthocyanins separation in 'Bluecrop' variety is presented in Fig. 1.

In Vaccinium myrtillus, petunidin-3-glucoside and delphinidin-3-glucoside have the highest contribution to the anthocyanin content $(15.6 \%$ and $16.9 \% ; 17.3$ and $12.7 \%$ respectively). In Vaccinium corymbosum, peonidin-3-galactoside represent the major anthocyanin content in 'Elliot' and 'Duke' variety ( $40.3 \%$ and $30.3 \%$ ) but in 'Bluecrop' peonidin-3-glucoside is absent, peonidin-3-glucoside being the major contributors (17.3\%).
Tab. 3. Antioxidant activity for blueberry fruits, using four different complementary assays (FRAP, ABTS, ORAC, DPPH)

\begin{tabular}{ccccc}
\hline & $\begin{array}{c}\text { FRAP } \\
\mu \mathrm{M} \mathrm{Fe}+/ \mathrm{g}\end{array}$ & $\begin{array}{c}\text { ABTS } \\
\text { TE } \mu \mathrm{mol} / \mathrm{g}\end{array}$ & $\begin{array}{c}\text { ORAC } \\
\text { TE } \mu \mathrm{mol} / \mathrm{g}\end{array}$ & $\begin{array}{c}\text { DPPH. } \\
\text { scavenging } \\
\text { activity (\%) }\end{array}$ \\
\hline \multicolumn{5}{c}{ Vaccinium corymbosum } \\
\hline 'Elliot' & $50.74 \pm 1.9^{\mathrm{c}}$ & $36.46 \pm 4.26^{\mathrm{c}}$ & $38.05 \pm 1.56^{\mathrm{a}}$ & $43.48 \pm 1.9^{\mathrm{d}}$ \\
'Bluecrop' & $60.39 \pm 1.6^{\mathrm{b}}$ & $37.96 \pm 2.98^{\mathrm{bc}}$ & $37.04 \pm 1.7^{\mathrm{a}}$ & $46.64 \pm 1.65^{\mathrm{c}}$ \\
\hline 'Duke' & $33.03 \pm 2.54^{\mathrm{d}}$ & $24.33 \pm 3.76^{\mathrm{d}}$ & $34.85 \pm 1.3^{\mathrm{b}}$ & $29.96 \pm 1.38^{\mathrm{e}}$ \\
\hline \multicolumn{5}{c}{ Vaccinium myrtillus } \\
\hline Wild 1 & $73.71 \pm 3.2^{\mathrm{a}}$ & $56.65 \pm 3.79^{\mathrm{a}}$ & $38.49 \pm 1.01^{\mathrm{a}}$ & $59.79 \pm 1.24^{\mathrm{a}}$ \\
\hline Wild 2 & $64.87 \pm 2.9^{\mathrm{b}}$ & $43.08 \pm 2.3^{\mathrm{b}}$ & $37.78 \pm 0.89^{\mathrm{a}}$ & $49.93 \pm 1.6^{\mathrm{b}}$ \\
\hline \multicolumn{5}{c}{}
\end{tabular}

\section{Total antioxidant activity}

For measuring the total antioxidant activity of the blueberry extracts, four different assays were used. Tab. 3 includes the mean values for antioxidant activity measured.

ORAC assay is probably the most widely used HATbased assay and indicate the free-radical scavenging ability of antioxidant against peroxyl radical. The values obtained were not significantly different among samples, ranging from 34.85-38.49 $\mu \mathrm{mol} \mathrm{TE} / \mathrm{g}$ fresh weight. The present ORAC results are similar to those obtained by Prior $e t a l$. (1998) (17-37.1 $\mu \mathrm{mol} \mathrm{TE} / \mathrm{g})$ and lower than the values reported for rabbiteye blueberries by You et al. (2011) (44$55 \mu \mathrm{mol} \mathrm{TE} / \mathrm{g}$ ). For 'Duke' variety, it has been obtained $34.85 \mu \mathrm{mol}$ TE/g comparable with the values reported by Wang et al. (2009) $(40.4 \mu \mathrm{mol} \mathrm{TE} / \mathrm{g})$ and Moyer $e t$ al. (2002) (32.6 umol TE/g). Regarding the ORAC values for 'Bluecrop' variety it is a great discrepancy in the literature data. Prior et al. (1998), reported $17 \mathrm{mM} \mathrm{TE} /$ $\mathrm{kg}$, Moyer et al. (2002), $50 \mathrm{mM} \mathrm{TE} / \mathrm{kg}$ and Howard et al. (2003), between $21-38 \mathrm{mM} \mathrm{TE} / \mathrm{kg}$, the last values being comparable with the present value. The last mention study indicates that genotypes influence more the TPC and ORAC values than growing season.

ABTS assay is based on the antioxidant ability of the extracts to react with $\mathrm{ABTS}^{+}{ }^{+}$radical cation generated in the system. In contrast, the ferric reducing antioxidant power assay (FRAP) measures the ability of the extracts to reduce ferric complex to the ferrous form. The averages values obtained for ABTS and FRAP assay are given in Tab. 2. Blueberries Wild 1 extract showed the highest antioxidant activity based on FRAP and ABTS assay (73.71 $\mu \mathrm{M} \mathrm{Fe}^{2+} / \mathrm{g}$ and $56.65 \mu \mathrm{mol} \mathrm{TE} / \mathrm{g}$ ). The lowest level in both assays was obtained for 'Duke' variety. The antioxidant activity order in both assays, FRAP and ABTS, was: Wild 1>Wild 2>'Bluecrop'>'Elliot' >'Duke'. In FRAP assay, there were significant differences found between Wild 1 , Wild 2, 'Bluecrop' and 'Duke' ( $p<0.05)$. In ABTS assay, significant differences were found between Wild 1 , Wild 2 , 'Elliot' and 'Duke' $(p<0.05)$. There were no statistical differences between 'Elliot' and 'Bluecrop' varieties. 
Tab. 4. Pearson's correlation coefficients of antioxidant activity (FRAP, ABTS, ORAC, DPPH), total polyphenol content (TPC), total flavonoid (TF) and total anthocyanin (TA) in blueberries

\begin{tabular}{ccccccc}
\hline & TA & TF & FRAP & ABTS & ORAC & DPPH \\
\hline TPC & $0.923^{*}$ & 0.914 & $0.975^{* *}$ & $0.966^{*}$ & $0.765^{\text {ns }}$ & $0.973^{* *}$ \\
TA & - & $0.894^{*}$ & $0.919^{*}$ & $0.961^{* *}$ & $0.805^{\text {ns }}$ & $0.939^{*}$ \\
TF & & - & $0.95^{*}$ & $0.853^{\text {ns }}$ & $0.739^{\text {ns }}$ & $0.896^{*}$ \\
FRAP & & & - & $0.951^{*}$ & $0.858^{\text {ns }}$ & $0.985^{* *}$ \\
ABTS & & & - & $0.853^{\text {ns }}$ & $0.986^{* *}$ \\
ORAC & & & & - & $0.891^{*}$ \\
DPPH & & & & & - \\
${ }^{* * *}$ significant at $\mathrm{p}<0.05$ and 0.01 , respectively & &
\end{tabular}

The range of FRAP values in the present study (33.03$73.71 \mu \mathrm{M} \mathrm{Fe}^{2+} / \mathrm{g}$ ) was generally higher than those reported by Koca and Karadeniz (2009) (7.41-13.69 $\mu \mathrm{mol} / \mathrm{g}$ for cultivated and 34.45-57.92 umol/g for wild blueberries). The present ABTS values are higher than the values obtained by Sellappan et al. (2002) (8.11-38.29 $\mu \mathrm{mol} / \mathrm{g})$.

High level of antioxidant activity obtained for Wild 1 blueberries, by all the methods used, could be due to its high level of total polyphenol and total anthocyanin content.

The DPPH. scavenging activity of blueberries extract is presented in Tab. 4. It has been obtained significant differences between all the blueberry extracts analyzed, with the highest value for Wild 1 (59.79\%) and the lowest for 'Duke' variety (29.96\%). The present data are in agreement with previously reported data: $34.13 \%$ of inhibition for wild blueberries (Li et al., 2009) and 28\% of inhibition (Ogawa et al., 2008).

The kinetic curves presented in Fig. 2 clearly indicated that Wild 1 and 2 blueberries had the highest scavenging activity during 30 minutes.

In Tab. 4 are presented the Pearson's coefficients, which indicate the possible correlation between polyphenol composition with different antioxidant activity and the correlation of different assays used with each other.

A correlation analysis was done among total polyphenols content, total flavonoid, total anthocyanin and the antioxidant activity values obtained (Tab. 4). The total polyphenols content (TPC), total flavonoids (TF) and total anthocyanins (TA) exhibit a significant correlation $(\mathrm{p}<0.05$ and $\mathrm{p}<0.01)$ with different antioxidant methods with a decreasing order of TPC $>\mathrm{TA}>\mathrm{TF}$. This suggests that antioxidant activity is more correlated to TPC than TA. These results are in agreement with other studies (Giovanelli and Buratti, 2009; Koca and Karadeniz, 2009; Prior $e t$ al., 1998). The high correlation between the FRAP and TPC content can be attributed to the fact that both assays rely on the same reaction mechanism.

There were no statistically significant correlation between ORAC values and TPC, TF and TA. Tabart et al. (2009) found no correlation between ABTS or DPPH values and ORAC data's applied on different phenolic standards. The highest Pearson's coefficient between was obtained when it has been compared ABTS and DPPH antioxidant methods (0.986). As mentioned before, these two assays are also based on similar mechanisms.

\section{Conclusions}

There were analyzed, for the first time, the antioxidant activity in relation to the polyphenol content in wild and some cultivated blueberry fruits from Romania. Total polyphenol, total anthocyanin, total flavonoid content and antioxidant activity measured with six different assays were higher in wild blueberry varieties, as compared with cultivated ones. The FRAP, ABTS and DPPH assays showed higher correlation, statistically significant, with total polyphenol content compared with total anthocyanin content. To measure adequately the antioxidant potential ABTS and DPPH methods are considered to be most appropriate, in good agreement with the concentrations of phenolic derivatives (polyphenols, anthocyanins, flavonoids).

\section{Acknowledgment}

This research was supported by CNCSIS-UEFISCSU, project number PNII-TE_168, code 109/2010. The second author's work was supported by European Postdoctoral Program POSDRU/89/1.5/S/60746. The authors thank Natural Invest for providing the blueberry cultivars.

\section{References}

Arnao MB, Cano A, Alcolea JF, Acosta M (2001). Estimation of free radical-quenching activity of leaf pigment extracts. Phytochem Anal 12:138-143.

Beekwilder J, Jonker H, Meesters P, Hall RD, Van der Meer IM, Ric de Vos CH (2005). Antioxidants in raspberry: on-line analysis links antioxidant activity to a diversity of individual metabolites. J Agric Food Chem 53:3313-3320.

Benzie IFF, Strain JJ (1996). The ferric reducing ability of plasma (FRAP) as a measure of ,antioxidant power“: the FRAP assay. Anal Biochem 239:70-76.

Brand-Williams W, Cuvelier ME, Berset C (1995). Use of a free radical method to evaluate antioxidant activity. Food Sci Technol 28:25-30.

Canter PH, Ernst E (2004). Anthocyanosides of Vacinnium myrtillus (bilberry) for night visions a systematic review of placebo controlled trials. Surv Ophthalmol 49:38-50.

Castrejón ADR, Eichholz I, Rohn S, Kroh LW, HuyskensKeil S (2008). Phenolic profile and antioxidant activity of highbush blueberry (Vaccinium corymbosum L.) during fruit maturation and ripening. Food Chem 109:564-572.

Dragović-Uzelac V, Savić Z, Brala A, Levaj B, Bursač Kovačević D, Biško A (2010). Evaluation of phenolic content and antioxidant capacity of blueberry cultivars (Vaccinium 
76 corymbosum L.) grown in the Nortwest Croatia. Food Technol Biotech 48:214-221.

El-Sayed MAA, Hucl P (2003). Composition and stability of anthocyanins in blue-grained wheat. J Agric Food Chem 51:2174-2180.

Garzón GA, Narváez CE, Riedl KM, Schwartz SJ (2010). Chemical composition, anthocyanins, non-anthocyanin phenolics and antioxidant activity of wild bilberry (Vaccinium meridionale Swartz) from Colombia. Food Chem 122:980986.

Giovanelli G, Buratti S (2009). Comparison of polyphenolic composition and antioxidant activity of wild Italian blueberries and some cultivated varieties. Food Chem 112:903-908.

Giusti MM, Wrolstad RE (2001). Characterization and measurement of anthocyanins by UV-Visible spectroscopy. John Wiley \& Sons, Inc., New York.

Howard LR, Clark JR, Brownmiller C (2003). Antioxidant capacity and phenolic content in blueberries as affected by genotype and growing season. J Sci Food Agric 83:12381247.

Huang D, Ou B, Hampsch-Woodill M, Flanagan JA, Prior RL (2002). Highthroughput assay of oxygen radical absorbance capacity (ORAC) using a multichannel liquid handling system coupled with a microplate fluorescence reader in 96well format. J Agric Food Chem 50:4437-4444.

Kim DO, Jeong SW, Lee CY (2003). Antioxidant capacity of phenolic phytochemicals from various cultivars of plums. Food Chem 81:321-326.

Koca I, Karadeniz B (2009). Antioxidant properties of blackberry and blueberry fruits grown in the Black Sea Region of Turkey. Sci Hortic 121:447-450.

Kresty LA, Morse MA, Morgan C, Carlton PS, Lu J, Gupta A, Blackwood M, Stoner GD (2001). Chemoprevention of esophageal tumorigenesis by dietary administration of lyophilized black raspberries. Cancer Res 6:6112-6119.

Lee J, Finn CE, Wrolstad RE (2004). Comparison of anthocyanin pigment and other phenolic compunds of Vaccinium membranaceum and Vaccinium ovatum native to the Pacific Nortwest of North America. J Agric Food Chem 52:7039-7044.

Li W, Hydamaka AW, Lowry L, Beta T (2009). Comparison of antioxidant capacity and phenolic compounds of berries, chokecherry and seabuckthorn. Cent Eur J Biol 4:499-506.

Martineau LC, Couture A, Spoor D, Benhaddou-Andaloussi A, Harris C, Meddah B, Leduc C, Burt A, Vuong T, Le PM, Prentki M, Bennett SA, Arnason JT, Haddad PS (2006). Anti-diabetic properties of the Canadian lowbush blueberry Vaccinium angustifolium Ait. Phytomedicine 13:612-623.

Moyer RA, Hummer KE, Finn CE, Frei B, Wrolstad RE (2002). Anthocyanins, phenolics and antioxidant capacity in diverse small fruits: Vaccinium, Rubus and Ribes. J Agric Food Chem
50:519-525.

Ogawa K, Sakakibara H, Iwata R, Ishii T, Sato T, Goda T, Shimoi K, Kumazawa S (2008). Anthocyanin composition and antioxidant activity of the crowberry (Empetrum nigrum) and other berries. J Agric Food Chem 56:4457-4462.

Pineli LLO, Moretti CL, Santos MS, Campos AB, Brasileiro AV, Cordova AC, Chiarello MD (2011). Antioxidants and other chemical and physical characteristics of two strawberry cultivar at different ripeness stages. J Food Compos Anal 24:11-16.

Prior RL, Cao G, Martin A, Sofic E, McEwan J, O’Brien C, Lischner N, Ehlenfeldt M, Kalt W, Krever G, Mainland CM (1998). Antioxidant capacity as influenced by total phenolic and anthocyanin content, maturity and variety of Vaccinium species. J Agric Food Chem 46:2686-2693.

Sariburun E, Şahin S, Demir C, Türkben C, Uylaşer V (2010). Phenolic Content and Antioxidant Activity of Raspberry and Blackberry Cultivars. J Food Sci 4:C328-C335.

Sellappan S, Akoh CC, Krewer G (2002). Phenolic compounds and antioxidant capacity of Georgia-grown blueberries and blackberries. J Agric Food Chem 50:2432-2438.

Singleton VL, Orthofer R, Lamuela-Raventós RM, Lester P (1999). Analysis of total phenols and other oxidation substrates and antioxidants by means of Folin-Ciocalteu reagent. Meth Enzymol 299:152-178.

Steffen LM, Jacobs JDR, Stevens J, Shahar E, Carithers T, Folsom AR (2003). Associations of whole-grain, refinedgrain, and fruit and vegetable consumption with risks of all-cause mortality and incident coronary artery disease and ischemic stroke: The Atherosclerosis Risk in Communities (ARIC) Study. Am J Clin Nutr 78:383-390.

Tabart J, Kevers C, Pincemail J, Defraigne JO, Dommes J (2009). Comparative antioxidant capacities of phenolic compounds measured by various tests. Food Chem 113:1226-1233.

Valentová K, Ulrichová J, Cvak L, Simánek V (2007). Cytoprotective effect of a bilberry extract against oxidative damage of rat hepatocytes. Food Chem 101: 912-917.

Wang CY, Chen CT, Wang SY (2009). Changes of flavonoid content and antioxidant capacity in blueberries after illumination with UV-C. Food Chem 117:426-431.

Wang SY, Jiao H (2000). Antioxidant activity in fruits and leaves of blackberry, raspberry and strawberry varies with cultivar and developmental stage. J Agric Food Chem 48:140-146.

You Q, Wang B, Chen F, Huang Z, Wang X, Luo PG (2011). Comparison of anthocyanins and phenolics in organically and conventionally grown blueberries in selected cultivars. Food Chem 125:201-208.

Zadernowski R, Naczk M, Nesterowicz J (2005). Phenolic acid profiles in some small berries. J Agric Food Chem 53:21182124. 